\title{
Ends and Means
}

\author{
Jan-Erik Lane \\ Emeritus, University of Geneva, Geneva, Switzerland \\ Email: janeriklane34@googlemail.com
}

How to cite this paper: Lane, J.-E. (2021). Ends and Means. Open Journal of Philosophy, 11, 211-214.

https://doi.org/10.4236/ojpp.2021.111016

Received: February 2, 2021

Accepted: February 23, 2021

Published: February 26, 2021

Copyright $\odot 2021$ by author(s) and Scientific Research Publishing Inc. This work is licensed under the Creative Commons Attribution International License (CC BY 4.0).

http://creativecommons.org/licenses/by/4.0/

\begin{abstract}
The social sciences in a wide sense and the Humanities share one major focus, namely the acting person. The greatest social scientist in modern times argued that human action had to modelled as purposeful, driven by means and ends (Weber, 2012). Is Max Weber now old fashioned?
\end{abstract}

\section{Keywords}

Dawkins, Searle, Weber, Wilson

\section{Introduction}

R. Dawkins advocates an advanced form of Darwinism, focusing on selfishness, not of individuals but of genes. He adds genetics to Darwin's survival of the fittest principle (Dawkins, 2020). If one can say that the selfish gene in animals is selected as the most effective gene, could one then say that also persons with an effective genome are an evolutionary outcome? Compare Neanderthals against Homo Sapiens! If selfishness explains the animal kingdom, then maybe selfishness matters as much for humans? Hobbes and Spinoza argued that human affairs are typically characterized by universal egoism (Hobbes, 2016; Spinoza, 1992). Socio-biology claims that human behaviour is half genome half culture (Wilson, 2020).

\section{Physicalism as Reductionism}

The search for finding the most basic UNITS of the universe whatever those may be: quarks, strings or quantum waves, is very conspicuous today. How about the humanities and the social sciences, when persons are approached without minds or sense data concepts as in common sense?

Dawkins emphasizes that his selfish gene has no conscious drive or reasonable motive. But he talks incessantly about the strategy of genes.

\section{Human Action}

Weber was, in addition to a political scientist and economic historian, a philo- 
sopher of science. His Collected Papers in the Philosophy of Science is a book published after his death in 1920, making him one of the most influential philosophers of science besides Popper, Nagel, Hempel and Kuhn.

Weber identified the basic micro unit in social science analysis as intentional behaviour. He underlined intention: Sinn or meaning-the inner side of behaviour: thought, belief, will, etc. When outer behaviour was directed by complex Sinn, there was Sinnzusa

Advanced Darwinians argue that an animal tends to select the best gene from the gene pool from the point of view of survival. It is not a choice or decision, but clever selfish evolution by the individual animal-automatically. The elegance as well as effectiveness of Dawkins' arguments make one ask if human actions can be analysed and explained similarly?

Selfishness and altruism are well known concepts in political philosophy.

Dawkins interprets animal evolution as natural selection by selfish genes. Is there a circular argument here? Consider:

1) Animal $x$ survives

2) Animals that survive are selection optimal.

3) An animal that is selection optimal survives.

Dawkins speaks of selfish genes being selected from a huge gene pool.

Contrary, the humanities and social sciences understand outer behaviour by advancing intention or motive. Weber called it "deutend verstehen".

This emphasis on the basic subjective nature of human activity opens up for the analysis of ideas, plans, hopes, etc.

In the animal kingdom there are hardly such motives for Dawkins. In the human or social reality, common sense emphasizes intention or reason as key: Action $=$ intention + behaviour. If animal behaviour lacks intention, perhaps intention is superfluous also for human activity?

\section{One Reality}

If the world only consists of words and objects (Putnam, 1975), where to place beliefs? The philosophy of mind has no accepted recognition that goals drive behaviour. Where are objectives located: in brain neurons or synapses?

Searle argues now on YouTube 2020 Lectures that we have: new realism-one reality (Searle, 2004). Earlier Searle admitted that intentions could be "ontologically subjectively" phenomena. Thus, there would be more than one reality. We often explain the observable world, the sense data, with unobserved entities. Both would be "real".

\section{Ends and Means}

Weber declared that every action could be analysed with the means-end framework for understanding the inner aspect, intention. This is weak rationality with few restrictions on how means and ends are identified or related. Is means and ends in intention merely a teleological relation? That is just beliefs, whether true 
or false? Or causality meaning true beliefs about means and ends. Weber's action model is nothing but the rational choice framework when utility and probability is added. He analysed religious thought with the virtuosi in the same paradigm e.g. salvation theory (Weber, 1922).

Searle lives in a so-called material world, whatever this may be: particles, atoms, waves, strings. Weber lived in the sense data world.

Ends and means refer to a person's beliefs and reasons. Take away the persons and these beliefs do not exist.

\section{Subjective Meaning}

Intention is so-called mind phenomenon, see an excellent overview on Jacob (2018) (Jacob, 2019). Instead of debating the classic mind-body problematic I will argue that the concepts of ends and means cannot be reduced somehow to natural science concepts. Both the humanities and the social sciences start from the person in the sense data world. Without goals and means no deliberate action.

Consider Germany summer 1940 (Kershaw, 2020). Hitler had gambled successfully in the spring. Now what? Objectives? Never had Germany been so dominant.

Goals direct action or orientated it, as Parsons said (Parsons, 1937), e.g.: it took Hitler and Wehrmacht one year to arrive at a means-end concept for the attack on USSR. Ends become real by the employment of means. They are not self-selected or reducible to brain functions. The post 1940 summer plans saw goal mistakes after means mistakes: wrong goals or objectives and insufficient means on all theatres, sending millions of German youth to ugly death. Ends against real outcomes, means versus real causes.

\section{Conclusion}

The animal kingdom consists of selection machines in Dawkins' world. Can human selfishness be accounted for by genomes?

Or, humans engage in means-end projects expressing both values and knowledge or lack of both of them leading to defeat or misfortune.

The present trend in philosophy towards behaviourism or reductionism does not suit the social sciences or humanities. The concept of intention (Anscombe, 1957) remains as central as it was to Weber in sociology and Menger in economics.

Socio-biology may succeed in reducing animal behaviour to selfish genome. Human egoism may be all important but it does not drive a selection machine.

\section{Conflicts of Interest}

The author declares no conflicts of interest regarding the publication of this paper. 


\section{References}

Anscombe, G. E. M. (1957). Intention. Oxford: Blackwell.

Dawkins, R. (2020). The Selfish Gene. Newark, New Jersey: Audible.

Hobbes, T. (2016). Leviathan. London: 1 Penguin.

Jacob, P. (2019). Intentionality. In Stanford Encyclopedia of Philosophy.

Kershaw, I. (2020). Hitler. Newark, New Jersey: Audible.

Parsons, T. (1937). The Structure of Social Action.

Putnam, H. (1975). Philosophical Papers: Mind, Language.

Searle, J. (2004). Mind, Language and Reality. Cambridge: CUP.

https://www.cambridge.org/core/books/philosophical-papers/708D9D069C33E70181B 5AF944228714A? cf chl jschl tk =48099652f5a5e0a1573b81ce962255397c72ac17-1 614649577-0-ATDg-CYHWvgIWTGb-lhLNFriXrGWpecu2AL7TbIW 0qWVfeIwcihe aPAZj5g0WQydu6jJvn7yxxsmUmfksVUC8F2NMg8dJXRqQsmwRyiFHJmX2hsYmN MghPNBSml2NGnz-UKHBdsazY 1uuYvHbWUZvWx8ZYula-eGDSTghDmuauxN 1 s0h0RSiKU22eZmEQABNqjySUSM6w84aQWFbUKT-Me8siSpeeXVcB5K3oXQxbdpU LrlMKpFyoBHvx6pdo tl] hY9YNyd2yptTlF87lFS4ZabeiJlQV5J d50uV40oILv5 i7Y7 BHlRswslk6lXZ--O88VZb10OZwNXgCy3QduqyP75lBr0NW94TNmWfdXVMiQriW WVyTvxeCW4nHm2vfkFhAkAakqtopNT9n7xbd5wkTWxV0xlYmpTUVcZtZaIUeVzUMPU6 FeWBVCjiI5JULkjdG2YJwFaLNEL-1Bpo

Spinoza, B. (1992). Traite Politique. Paris: Flammarion.

Weber, M. (1922).Gesammelte Aufsatze źur Religionssoziologi I-III. Tubingen: Mohr. Weber, M. (2012). Collected Methodological Writings. London: Routledge.

Wilson, E. O. (2020). Consilience. Newark, New Jersey: Audible. 